\title{
Organosolvent Extraction Coupled with Steam Explosion Pretreatment of Wild Sugarcane and Optimization of Cellulase Activity using Response Surface Methodology
}

\section{S. Aruna (iD) and Sriramulu Gobikrishnan (D)* \\ Department of Food Processing Technology, School of Agriculture and Biosciences, Karunya Institute of Technology and Sciences, Coimbatore - 641 114, Tamil Nadu, India.}

\begin{abstract}
The present study focuses on the effect of the organosolvent extraction with steam explosion pretreatment and optimization of cellulase activity using the response surface methodology for the production of bioethanol. The commercial cellulase enzyme was characterized for its optimal pH, temperature, and also studied for the enzyme activity. The effect of organosolvent pretreatment was identified in both native and pretreated wild sugarcane by SEM, XRD, and FTIR. The cellulase enzyme was found to be tolerant with an optimal $\mathrm{pH}$ of 5.0 with cellulase activity of pretreated wild sugarcane is found to be $25.36 \mathrm{IU} / \mathrm{ml}$. Organosolvent extraction of wild sugarcane was carried out using water and ethanol as solvent. The composition of lignin, hemicelluloses, and cellulose was also determined in both pretreated and native biomass. The activity of the enzyme was observed over the effect of enzyme loading, substrate loading, temperature, and pH using a Box-Behnken design.
\end{abstract}

Keywords: Organosolvent extraction, Response Surface Methodology, Cellulase activity, XRD, FTIR, SEM

*Correspondence: suguraj200@gmail.com; +919487714788

(Received: September 14, 2020; accepted: January 05, 2021)

Citation: Aruna S, Gobikrishnan S. Organosolvent Extraction Coupled with Steam Explosion Pretreatment of Wild Sugarcane and Optimization of Cellulase Activity using Response Surface Methodology. J Pure Appl Microbiol. 2021;15(1):114-122. doi:10.22207/JPAM.15.1.06

(c) The Author(s) 2021. Open Access. This article is distributed under the terms of the Creative Commons Attribution 4.0 International License which permits unrestricted use, sharing, distribution, and reproduction in any medium, provided you give appropriate credit to the original author(s) and the source, provide a link to the Creative Commons license, and indicate if changes were made. 


\section{INTRODUCTION}

Bioethanol is ecofriendly since it is produced from renewable energy sources of biomass which can be utilized as an alternative to fossil fuel ${ }^{1}$. To get better of a dispute regarding the usage of human food, lignocellulosic materials can be used as the feedstock for the production of bioethanol. Global warming and the increase in atmospheric $\mathrm{CO}_{2}$ are happening due to the consumption of fossil fuel, to overcome this issue it is necessary to focus on bioethanol ${ }^{2}$. Biofuel feedstocks are renewable energy products consists of high carbon concentration $(C)$, hydrogen $(H)$, low oxygen concentration (O), nitrogen $(\mathrm{N})$, and inorganic constituents such as ( $\mathrm{Ca}, \mathrm{Mg})$, which releases energy during its conversion process which helps to regulate the temperature in the environment ${ }^{3}$. Bioethanol produced from biomass is also known as Modern biofuels that provide good-quality energy have a use for transportation fuel ${ }^{4}$. Plant biomass consists of carbohydrates such as cellulose, hemicelluloses, starch, and pectin which can be a suitable substrate for biofuel production ${ }^{5}$. The development of new lignocellulosic feedstock with minimum lignin concentration may be an efficient and cost-effective strategy for the development of lignocellulosic biomass bioethanol. Saccharum Spontaneum (wild sugarcane) consists of cell wall substances rich in cellulose, hemicellulose, and pectin but minimal in lignin. For the removal of lignin various pretreatment methods are used. Compared with other pretreatment methods the high yield of glucose and xylose were caused by a steam explosion ${ }^{6}$. The method explodes biomass by rapid depressurization from extreme temperature and pressure situations to increase the responsiveness of cell wall content to cellulase thermal decomposition to achieve higher yields for subsequent fermentation. Steam explosion is a thermo-hydrolytic pretreatment process for enhancing enzymatic saccharification and synthesis of bioethanol ${ }^{7}$. Nevertheless, due to the high temperature and pressure anticipated and the development of inhibitors, the drawback is the high energy supply. Nowadays organosolvent pretreatment has been used for the removal of lignin and valuable co-product (e.g. acetone, butanol, biogas) production $^{8-13}$. Organosolvent pretreatment helps to increase the yield of conversion during fermentation by influencing the acid, enzymatic, and microbial action ${ }^{14}$. In 1893, organic solvents were used to treat the lignocellulosic material, to study the structure of carbohydrate and lignin, Klason ${ }^{15}$ used hydrochloric acid and ethanol to separate the components of wood. To balance the biological process of enzymatic hydrolysis of cellulose it is necessary to perform mathematical modeling with different variables ${ }^{16}$. Enzyme loading, substrate loading, temperature, and $\mathrm{pH}$ are the significant factors that influence the activity of the enzyme of pretreated biomass. To determine the optimal process parameters for optimization and modeling of several variables a statistical technique (RSM) Response surface methodology was used, this is done by combining the experimental results with the variables. The optimum parameters to gain the desired response can be predicted by using RSM with the experimental data, whereas the mathematical model interprets the connection between the responses and the experimental variables. In this study, for the production of bioethanol by organosolvent pretreatment the wild sugarcane was examined. For the conversion of cellulose into ethanol, the activity of the enzyme has a major role in hydrolysis and fermentation. To enhance the activity of the enzyme it is necessary to focus on the optimization of enzymatic conditions, this can be done by using RSM. Thus, the current study was aimed to know the efficiency of organosolvent extraction with steam explosion pretreatment to induce the structural and chemical changes made by thermophysical pre-treatment in the wild sugarcane.

\section{MATERIALS AND METHODS Feedstock}

The plant Saccharum spontaneum L (wild sugarcane) was collected from Ash Lake, Neyveli, Tamilnadu, India, and authenticated by the Botanical Survey of India (BSI), TNAU - BSI/ $\mathrm{SRC} / 2804$. The stem part of the plant was sundried, powdered, and stored at room temperature for further use.

\section{Organosolvent Extraction with steam explosion}

To a $250 \mathrm{ml}$ stoppered conical flask, $5 \mathrm{~g}$ of powdered sample was taken and mixed with ethanol and water in a 1:1 ratio. The mixture was 
kept for pretreatment in an autoclave under the conditions of $15 \mathrm{lb}$ pressure, $121^{\circ} \mathrm{C}$ temperature for 60minutes.After pretreatment, the samples are washed with distilled water to neutralize the $\mathrm{pH}$. The pretreated biomass is dried at room temperature and stored.

\section{Compositional Analysis}

The moisture and ash content of the feedstock was calculated by the standard method (AOAC 1990) ${ }^{17}$. Cellulose content was measured by the method described by (Norman and Jenkins $1933)^{18}$. Briefly, to $0.5 \mathrm{~g}$ or $1 \mathrm{~g}$ sample, $3 \mathrm{ml}$ of acetic/nitric reagent were added and kept for boiling at $100^{\circ} \mathrm{C}$ for 30 mins. The samples were cooled, centrifuged at $5000 \mathrm{rpm}$ and the residual pellet was washed with distilled water. To the washed pellet $10 \mathrm{ml}$ of $67 \%$ sulphuric acid was added. The solution was diluted 100 times and to the $1 \mathrm{ml}$ of diluted solution, $10 \mathrm{ml}$ of anthrone reagent was added and kept in a boiling water bath for 10 mins. The absorbance was measured at $630 \mathrm{~nm}$ and the amount of cellulose was calculated from the standard graph plotted with different concentrations of cellulose. The amount of lignin was determined by calculating acid detergent fiber and acid detergent lignin ${ }^{18}$. The amount of hemicellulose was estimated by the method described by (Norman and Jenkins 1933) ${ }^{19}$. SEM

SEM analysis was performed using (JOELJSM 6390, Japan) to study the differences between pretreated and native wild sugarcane based on its morphology. The magnification of the image is $500 \mathrm{X}$ whereas its accelerating voltage is $10-15 \mathrm{kV}$. XRD

XRD analysis was done using (XRD-6000 Schimadzudiffractometer) for the native and pretreated wild sugarcane. Diffraction patterns were reported utilizing $40 \mathrm{kV}$ and $30 \mathrm{~mA} \mathrm{Cu}-\mathrm{K} \alpha$ radiation and $10-30^{\circ}$ grade scale with a $0.03^{\circ}$ phase scale. The crystallinity index was calculated based on the equation

FTIR

$$
\operatorname{Crl}(\%)=\left[\left(I_{002}-\operatorname{lam}\right) / I_{002}\right] \times 100
$$

FT-IR spectroscopy (Shimadzu Spectrometer, Japan) was used to study the difference in structural and functional groups through the FT-IR spectrum which acts as a molecular fingerprint of the sample. The FT-IR spectrum is measured at the range of 4000 and $400 \mathrm{~cm}^{-1}$ and 50 scans for each sample.

\section{Enzyme activity}

Enzyme activity of steam-exploded wild sugarcane was performed in boiling tubes by heating $0.5 \mathrm{~g}$ of biomass in $1.0 \mathrm{~mL}$ of $0.05 \mathrm{M} \mathrm{Na}$ citrate buffer ( $\mathrm{pH} 4.8)$. The content was heated for $10 \mathrm{mins}$ at $50^{\circ} \mathrm{C}$. The enzyme assay was carried out using a commercial cellulase. $0.5 \mathrm{~mL}$ enzyme was added after appropriate dilution in citrate buffer to the tube. Blanks, controls, and glucose standards were also kept in a water bath along with the enzyme assay tubes at $50^{\circ} \mathrm{C}$ for 1 hour, Finally, $3.0 \mathrm{~mL}$ of 2,5-dinitrosalicylic acid was added to end the reaction and the absorbance was measured at $540 \mathrm{~nm}$. The amount of reducing sugar released was calculated using glucose standard and the enzyme activity (FPU) is determined based on the following equation

\section{Optimization of Enzyme activity by RSM}

To study the factor interactions with multiple combinations of variables and the response of independent variables Box-Behnken design was used. The selected variables were enzyme loading, substrate loading, temperature, and $\mathrm{pH}$. A total of 29 runs were used for the study and the effect of four variables was studied at three different levels. For the quadratic model building, experimental design, and data analysis the Design Expert Stat-Ease Version 12software was used. The experimental setup of RSM is shown in Table 1.

\section{RESULTS AND DISCUSSION}

Pretreatment, compositional analysis, and characterization of native and organosolvent extraction coupled with steam explosion pretreated biomass

The organosolvent extraction with steam explosion pretreated wild sugarcane upon enzyme activity yielded $25.36 \mathrm{IU} / \mathrm{mL}$ of cellulase activity/ gram of biomass after pretreatment. The cellulose, lignin, and hemicelluloses gained from $1 \mathrm{~g}$ of pretreated and native wild sugarcane is presented in Table 2. Steam explosion pretreatment is a delignification process. The porosity of biomass gets increased due to the removal of ester linkages. The difference between the pretreated and native biomass of wild sugarcane was identified from FTIR, 
Table 1. Activity of enzyme for individual runs of the RSM design

\begin{tabular}{|c|c|c|c|c|c|}
\hline $\begin{array}{l}\text { Trial } \\
\text { No. }\end{array}$ & $\begin{array}{c}\text { Temperature } \\
\left({ }^{\circ} \mathrm{C}\right)\end{array}$ & $\mathrm{pH}$ & $\begin{array}{l}\text { Substrate loading } \\
\text { (mg) }\end{array}$ & $\begin{array}{l}\text { Enzyme loading } \\
\text { in (ml) }\end{array}$ & $\begin{array}{l}\text { Activity of enzyme } \\
\text { in }(\mathrm{IU} / \mathrm{ml})\end{array}$ \\
\hline 1 & 40 & 4 & 50 & 0.7 & 10.70 \\
\hline 2 & 60 & 4 & 50 & 0.7 & 8.07 \\
\hline 3 & 40 & 6 & 50 & 0.7 & 10.60 \\
\hline 4 & 60 & 6 & 50 & 0.7 & 7.86 \\
\hline 5 & 48 & 5 & 30 & 0.4 & 22.13 \\
\hline 6 & 48 & 5 & 70 & 0.4 & 17.36 \\
\hline 7 & 48 & 5 & 30 & 1 & 19.32 \\
\hline 8 & 48 & 5 & 70 & 1 & 16.93 \\
\hline 9 & 40 & 5 & 50 & 0.4 & 15.77 \\
\hline 10 & 60 & 5 & 50 & 0.4 & 11.21 \\
\hline 11 & 40 & 5 & 50 & 1 & 16.03 \\
\hline 12 & 60 & 5 & 50 & 1 & 12.77 \\
\hline 13 & 48 & 4 & 30 & 0.7 & 16.69 \\
\hline 14 & 48 & 6 & 30 & 0.7 & 17.01 \\
\hline 15 & 48 & 4 & 70 & 0.7 & 15.78 \\
\hline 16 & 48 & 6 & 70 & 0.7 & 13.57 \\
\hline 17 & 40 & 5 & 30 & 0.7 & 14.86 \\
\hline 18 & 60 & 5 & 30 & 0.7 & 10.98 \\
\hline 19 & 40 & 5 & 70 & 0.7 & 13.49 \\
\hline 20 & 60 & 5 & 70 & 0.7 & 7.99 \\
\hline 21 & 48 & 4 & 50 & 0.4 & 18.54 \\
\hline 22 & 48 & 6 & 50 & 0.4 & 17.03 \\
\hline 23 & 48 & 4 & 50 & 1 & 17.53 \\
\hline 24 & 48 & 6 & 50 & 1 & 14.21 \\
\hline 25 & 48 & 5 & 50 & 0.7 & 25.36 \\
\hline 26 & 48 & 5 & 50 & 0.7 & 25.36 \\
\hline 27 & 48 & 5 & 50 & 0.7 & 25.36 \\
\hline 28 & 48 & 5 & 50 & 0.7 & 25.36 \\
\hline 29 & 48 & 5 & 50 & 0.7 & 25.36 \\
\hline
\end{tabular}

SEM, and XRD and analysis. From the SEM images, the changes between native and pretreated biomass were examined. Fig. 1 shows the SEM images of pretreated and native wild sugarcane. The pretreated biomass has a distorted complex whereas the native biomass has a compact rigid complex. The efficiency of the hydrolysis process will be increased when the biomass has increased surface area and distorted structure. Similar observations were reported earlier for sugarcane bagasse pretreated with formic $\mathrm{acid}^{20}$, bamboo pretreated with cold sodium hydroxide/urea ${ }^{21}$. The crystallinity changes of native and pretreated biomass were identified using the XRD spectrum. The pretreated and native $\mathrm{X}$-ray diffractograms are presented in Fig. 2 . The crystallinity indexes of pretreated native and pretreated samples were
$46.4 \%$ and $36.13 \%$. During the pretreatment, the glycosidic linkages of the cellulose fibers gethydrolyzed which increases the crystalline polymer directly increases the crystallinity Index. Similar observations have been identified in previous studies, such as organosolvent pretreated rice straw ${ }^{22}$ and pretreatment of switchgrass with $\operatorname{acid}^{23}$. Cellulose, hemicelluloses, and lignin are the important biopolymers which influence the lignocellulosic materials of FTIR spectra ${ }^{24}$. Fig. 3 presents the FTIR spectra of pretreated and native biomass. The differences are detected in absorption spectra. The band widening at 3652 $\mathrm{cm}^{-1}$ can be ascribed to $\mathrm{CH} 2$ wagging vibrations in cellulose. The characteristic band at $1828 \mathrm{~cm}^{-1}$ was assigned to lignin removal, guaiacylring of lignin which is present in the spectra of native 
biomass was found to be absent in the pretreated spectra, this indicates the removal of lignin after pretreatment. The disappearance of bands at 1828 $\mathrm{cm}^{-1}$ may be due to the depolymerization of lignin after pretreatment.

\section{Optimization of cellulase activity}

The enzymatic hydrolysis as an action of substrate loading, enzyme loading, $\mathrm{pH}$, and Temperature was evaluated. 29 trials were done with the combination of different factors and the response observed is presented in Table 1 . The interaction effects of variables on cellulase activity were studied to know the optimal response of each variable by plotting three-dimensional surface

Table 2. Composition of native and organosolvent pretreated wild sugarcane

\begin{tabular}{lcc}
\hline $\begin{array}{l}\text { Components } \\
(\% \mathrm{w} / \mathrm{w})\end{array}$ & Native & Pretreated \\
\hline Cellulose & 41.23 & 56.11 \\
Hemicellulose & 23.26 & 15.12 \\
Lignin & 11.21 & 5.64 \\
\hline
\end{tabular}

curves. The interaction of the variables from pretreated wild sugarcane on enzyme activity are shown in the surface plot given in Fig. 4a-f. Fig. 4a specifies the cellulase activity as a function of substrate loading and temperature. At a lower level of substrate loading and lower temperature, the activity of the enzyme was low. The results of the surface plot explain that temperature $\left(48^{\circ} \mathrm{C}\right)$ and biomass loading $(50 \mathrm{mg}$ ), the cellulase activity was high. From the results, increasing the temperature from 48 to $60 \mathrm{~h}$ does not increase the yield of wild sugarcane after pretreatment. The decrease in cellulase activity can be the result of the inhibition of the enzymes. Fig. $4 \mathrm{~b}$ indicates the interaction of enzyme activity between temperature and enzyme loading. Enzyme loading differs based on the pretreatment method and the composition of the feedstock used. The interaction effects of temperature and $\mathrm{pH}$ on enzyme activity are shown in Fig. 4c. This surface plot explained that, at lower levels of $\mathrm{pH}$ and higher levels of temperature, the enzyme activity was low. The enzyme activity increased with $\mathrm{pH} 5$ and temperature $48^{\circ} \mathrm{C}$, beyond that there was a reduction in the enzyme activity.
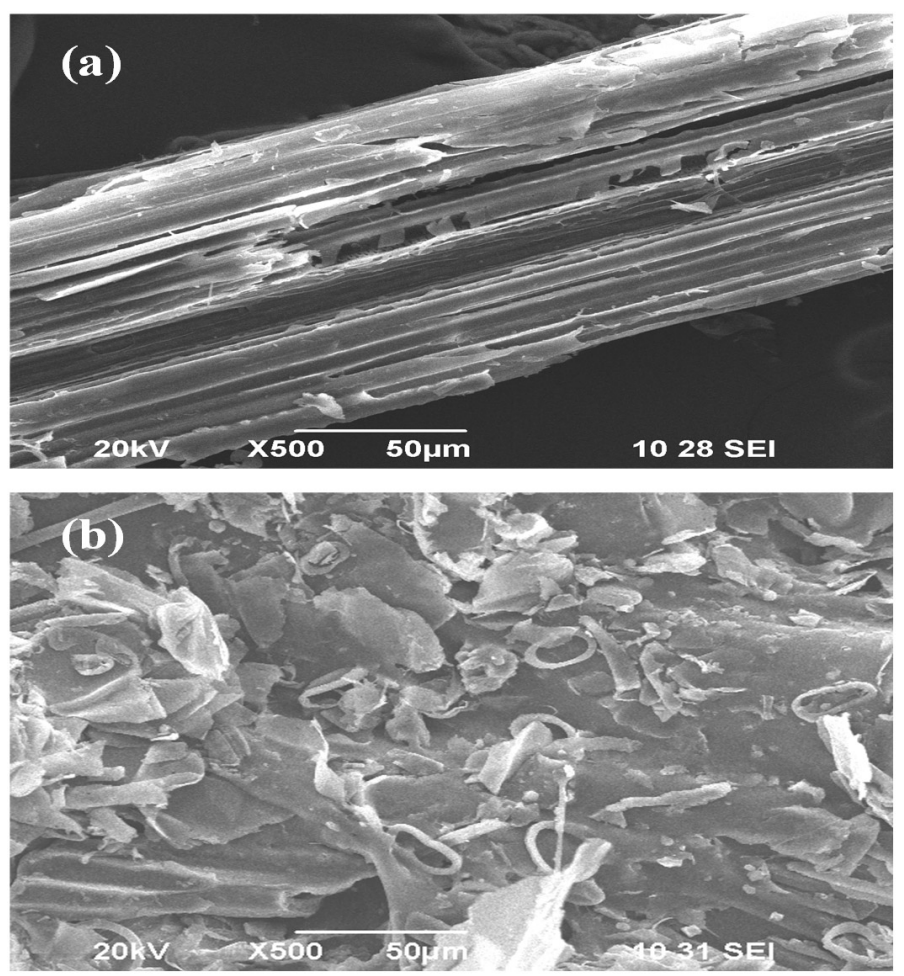

Fig. 1. SEM images of wild sugarcane (a) native, and (b) organosolvent pretreated wild sugarcane 
The impact of $\mathrm{pH}$ and substrate loading on enzyme activity is shown in Fig. $4 \mathrm{~d}$. At lower levels of $\mathrm{pH}$ and lower levels of substrate loading, the enzyme activity was low. This surface plot suggests that the maximum activity of cellulase was achieved at the middle level of $\mathrm{pH}$ concentration (5) and the middle level of substrate loading $(50 \mathrm{mg})$. The interaction on enzyme activity between enzyme loading and substrate loading is shown in Fig. $4 \mathrm{e}$.
At lower levels of substrate loading and lower levels of enzyme loading, the activity of the enzyme was low. This surface plot suggests that the middle-level of enzyme loading $(0.7 \mathrm{ml})$ and middle level of biomass loading (50mg), obtained a high enzyme activity. The interaction on enzyme activity between the $\mathrm{pH}$ and enzyme loading of wild sugarcane after pretreatment was presented in Fig. 4f. At lower levels of $\mathrm{pH}$ and lower levels

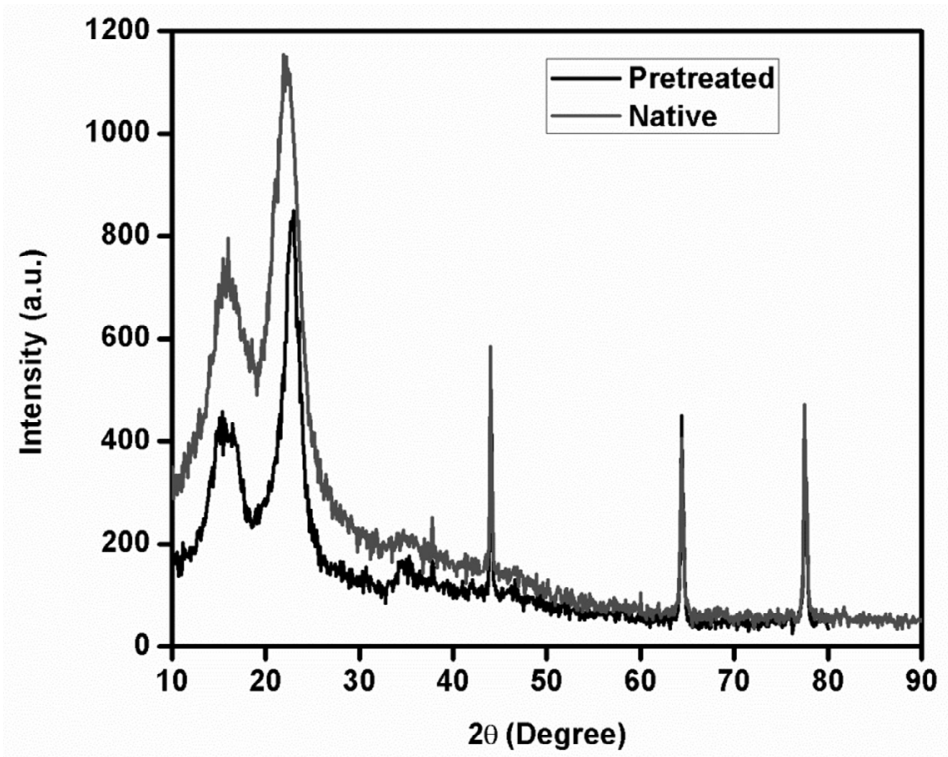

Fig. 2. X-ray diffraction pattern of native and organosolvent pretreated wild sugarcane.

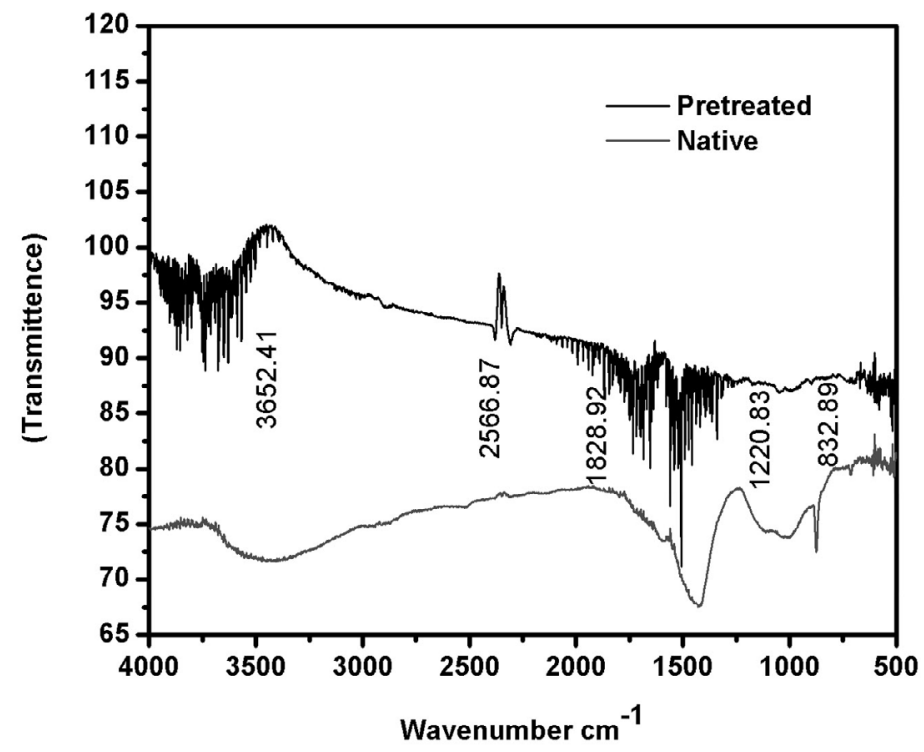

Fig. 3. FTIR spectra of native and organosolvent pretreated wild sugarcane. 

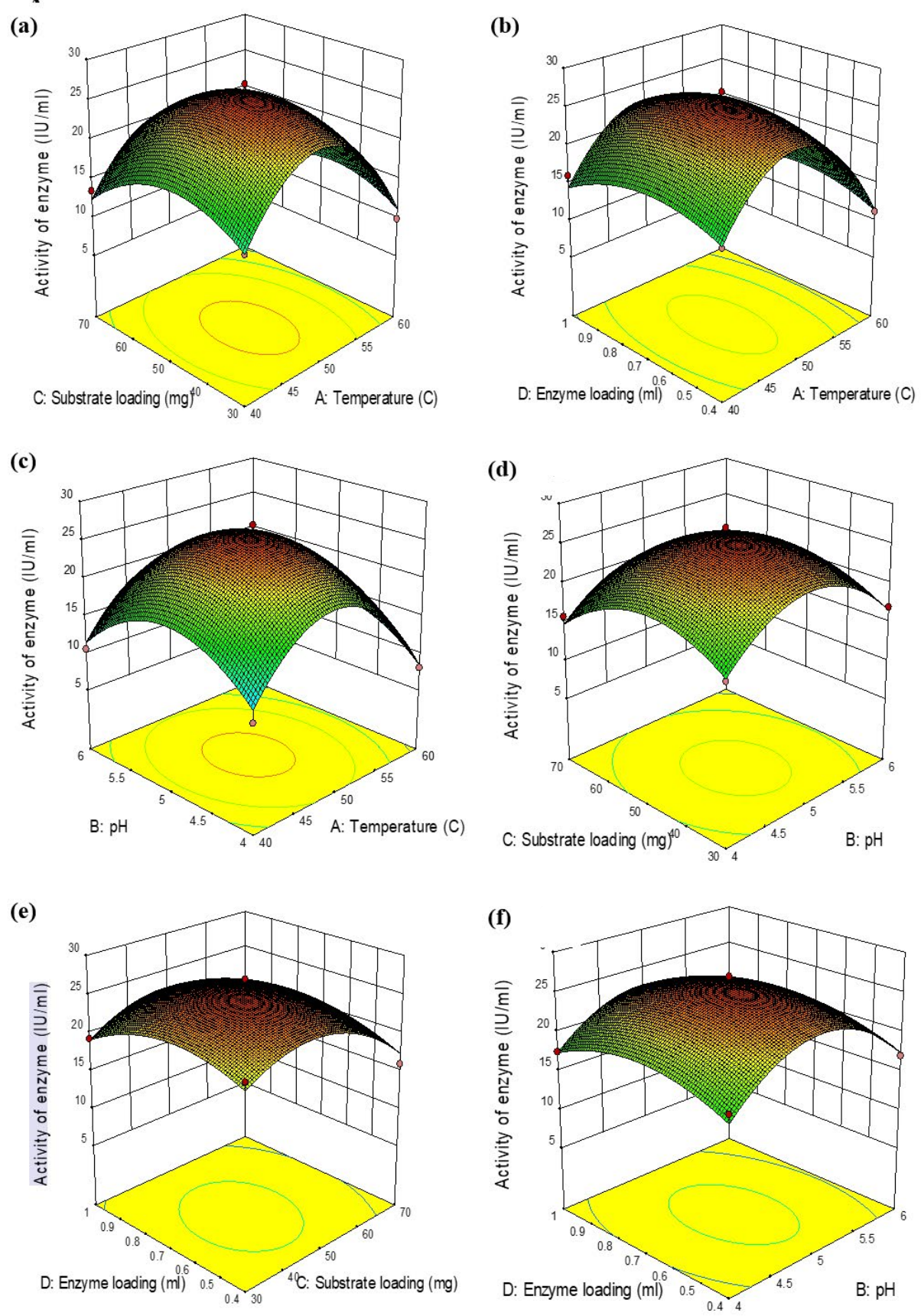

Fig. 4. Effect of various parameters on cellulase activity of organosolvent pretreated wild sugarcane (a) Effect of substrate loading and temperature on cellulase activity (b) Effect of enzyme loading and temperature on cellulase activity (c) Effect of $\mathrm{pH}$ and temperature on cellulase activity (d) Effect of substrate loading and $\mathrm{pH}$ on cellulase activity (e) Effect of substrate loading and enzyme loading on cellulase activity and (f) Effect of enzyme loading and $\mathrm{pH}$ on cellulase activity. 
of enzyme loading, the enzyme activity was low. The optimum conditions for cellulase activity of organosolvent extraction with steam explosion pretreated wild sugarcane were biomass loading (50mg), enzyme loading $(0.7 \mathrm{ml}), \mathrm{pH}(5)$, and temperature $\left(48^{\circ} \mathrm{C}\right)$ with the activity of 25.36 $\mathrm{IU} / \mathrm{ml}$. The results indicated that organosolvent extraction with steam explosion pretreatment increased the yield of cellulose than to native wild sugarcane shown in Table. 2. From the results, it can conclude that the combined pretreatment of organosolvent extraction with a steam explosion is an effective method that can be further utilized for bioethanol production.

\section{CONCLUSION}

Organosolvent extraction with steam explosion pretreatment in optimizing the enzyme activity was done by Box-Behnken Design. This combinatorial pretreatment of wild sugarcane leads to an increased cellulase activity. The results have shown that acceptable correlations were found between the predicted and experimental yields. This study reveals that the cellulase activity was notably improved after the pretreatment because of the removal of lignin. After the pretreatment, the compositional analysis of the wild sugarcane resulted that $90 \%$ of the lignin being reduced when compared to the native wild sugarcane. Organosolvent extraction with steam explosion pretreatment made the biomass suitable for the enzyme activity due to the changes in its physicochemical characteristics. The optimization of cellulase activity including substrate loading, enzyme loading, $\mathrm{pH}$, and, Temperature, resulted in better interaction on cellulase activity IU/ml yield. This current study proves the wild sugarcane as a suitable feedstock for bioethanol production.

\section{ACKNOWLEDGMENTS}

This work was supported by the Department of Food Processing Technology, School of Agriculture and Biosciences, Karunya Institute of Technology and Sciences - 641114, Coimbatore, India.

\section{CONFLICT OF INTEREST}

The authors declare that there is no conflict of interest.

\section{AUTHORS' CONTRIBUTION}

This work is done by $A$. S. as research scholar and Dr. G. S. have been guided as an overall mentor of the work.

\section{FUNDING}

None.

\section{DATA AVAILABILITY}

All datasets generated during this study are included in the manuscript

\section{ETHICS STATEMENT}

This article does not contain any studies with human participants or animals performed by any of the authors.

\section{REFERENCES}

1. Spatari S, Bagley, DM, Maclean, HL. Life cycle evaluation of emerging lignocellulosic ethanol conversion technologies. Bioresour Technol. 2010;101(2):654-667. doi: 10.1016/j.biortech.2009.08.067

2. WMO, Greenhouse gas bulletin: the state of greenhouse gases in atmosphere using global observation up to December 2004. World Meteorological Organization, Geneva, Switzerland 2006. doi: 10.5194/egusphereegu2020-7651

3. Lal R. Crop residues as soil amendments and feedstock for bioethanol production. Waste Management. 2007;28: 747-758. doi: 10.1016/j.wasman.2007.09.023

4. Giampietro M, Ulgiati S, imentel D. Feasibility of largescale biofuel production: Does an enlargement of scale change the picture?. BioScience.1997;47(9):587-600. doi: $10.2307 / 1313165$

5. Lewandowski I, ScurlockJMO, Lindvall E, Christou M. The development and current status of perennial rhizomatous grasses as energy crops in the US and Europe.Biomass Bioenerg. 2003;25(4):335-361. doi: 10.1016/s0961-9534(03)00030-8

6. Pedersen M, Meyer AS. Lignocellulose pretreatment severity - relating $\mathrm{pH}$ to biomatrix opening. New Biotechnol.2010;27(6):739-750. doi: 10.1016/j. nbt.2010.05.003

7. Nathan M, Wyman C, Dale B, et al. Features of promising technologies for pretreatment of lignocellulosicbiomass. J Bioresour Technol. 2005;96(6):673-686. doi: 10.1016/j.biortech.2004. 06.025

8. Pan X, Gilkes N, Kadla J, et al. Bioconversion of hybrid poplar to ethanol and co-products using an organosolv fractionation process: optimization of process yields. Biotechnol Bioeng. 2006;94:851-861. doi: 10.1002/ bit.20905

9. Kim DE, Pan XJ. Preliminary study on converting hybrid poplar to high-value chemicals and lignin using organosolv ethanol process. Ind Eng Chem Res. 2010;49(23):12156-12163. doi: 10.1021/ie101671r 
10. Arato C, Pye EK, Gjennestad G. The lignol approach to biorefining of woody biomass to produce ethanol and chemicals. Appl Biochem Biotech. 2005;121:871-882. doi: 10.1007/978-1-59259-991-2_74

11. Fernando EF, Vallejos EM, Area MC. Lignin recovery from spent liquors from ethanol-water fractionation of sugarcane bagasse. Cell Chem Technol. 2010;44(9):311318.

12. Sidiras D, Koukios E. Simulation of acid catalysedorganosolv fractionation of wheat straw. Bioresource Technology. 2004;94(1):91-98. doi: 10.1016/j.biortech.2003.10.029

13. Araque E, Parra C, Freer J, et al. Evaluation of organosolv pretreatment for the conversion of Pinusradiata D. Don to ethanol. Enzyme Microb Technol. 2008;43(2):214219. doi: 10.1016/j.enzmictec.2007.08.006

14. Bing $Y$, Wyman C. Pretreatment: the key to unlocking low-cost cellulosic ethanol. Biofuels, Bioprod Biorefin. 2008;2:26-40. doi: 10.1002/bbb.49

15. Klason P. Bidrag till Kannedomenomsammansattningen of granensvedsamt de kemiskaprocesserna vid framstallning of cellulose darur. TekniskTidskrift, Afdelningen for KemiochMetallurgi. 1893;23(2):17-22. doi: $10.5962 /$ bhl.title.46828

16. Binod P, Janu KU, Sindhu R, Pandey A. Hydrolysis of lignocellulosic biomass for bioethanol production. In: Pandey A, Larroche C, Ricke SC (Eds.), Biofuels: Alternative Feedstocks and Conversion Processes. 2011;229-250. doi: 10.1016/b978-0-12-3850997.00010-3

17. AOAC.Official methods of analysis of the Association of Official Analytical Chemists. 1990;2: 15th ed. Washington, DC. doi: 10.1016/0003-2670(91)87088-o
18. Norman AG, Jenkins SH. A new method for the determination of cellulose, based upon observations on the removal of lignin and other encrusting materials. Biochem J. 1933;27(3):818-831. doi: 10.1042/bj0270818

19. O'dwyer MH.The hemicelluloses. III. The hemicellulose of American white oak. Biochem J. 1923;17(4-5):501509. doi: 10.1042/bj0170501

20. Sindhu R, Binod P, Nagalakshmi S, Janu KU, Sajna KV, Kurien N. Formic acid as a potential pretreatment agent for conversion of sugarcane bagasse to Bioethanol. Appl Biochem Biotech. 2010;162(2):23132323. doi: 10.1007/s12010-010-9004-2

21. Li M, Fan $Y, X u F$, Sun $R$, Zhang $X$. Cold sodium hydroxide/urea based pretreatment of bamboo for bioethanol production: characterization of cellulose rich fraction. Ind Crop Prod. 2010;32(3):551-559. doi: 10.1016/j.indcrop.2010.07.004

22. Sindhu R, Kutttiraja M, Binod P, Preeti VE, Sandhya SV, Vani S. Surfactantassisted acid pretreatment of sugarcane tops for bioethanol production. Appl Biochem Biotech. 2012;167(6):1513-1526. doi: 10.1007/s12010-012-9557-3

23. Samuel R, Pu Y, Foston M, Rgauskas AJ. Solid estate NMR characterization of switch grass cellulose after dilute acid pretreatment. Biofuels. 2010;1:85-90. doi: 10.4155/bfs.09.17

24. Adel AM, Abdelwahab ZH, Ibrahim AA, Al-Shemy MT. Characterization ofmicrocrystalline cellulose prepared from lignocellulosic materials part 1 acidcatalyzed hydrolysis. Bioresour Technol. 2010;101(12):44464455. doi: 10.1016/j.biortech.2010.01.047 